\title{
Giant lasers in the US threatened with closure
}

\author{
Pressure on the US Department of Energy's budget could see the Omega and Nike laser facilities being axed.
}

( ne of the world's most powerful laser systems is under the threat of closure. The 2019 President's Budget Request (PBR) for the US Department of Energy proposes that the University of Rochester's Laboratory for Laser Energetics (LLE) that hosts the giant Omega laser has its funding "ramped-down" over a period of 3 years starting October 2018 (go.nature.com/2FzL4Xc).

The Omega laser at the LLE is a 60-beam ultraviolet neodymium glass laser that employs frequency tripling and is capable of delivering $30 \mathrm{~kJ}$ of energy and $60 \mathrm{TW}$ of power onto a target less than $1 \mathrm{~mm}$ in diameter in one-billionth of a second. It measures $10 \mathrm{~m}$ tall and about $100 \mathrm{~m}$ in length. The laser was constructed in 1995 and has been used over the past 20 years for research into high-energy physics and intense laser-matter interactions, in particular research related to exploring inertial confinement fusion (ICF). In May 2008, the facility was upgraded with the addition of the Omega-EP (extended performance) laser featuring a vacuum pulse compression chamber to allow shorter-pulse laser shots.

However, in recent years, Omega has arguably fallen under the shadow of the more powerful National Ignition Facility (NIF) at Lawrence Livermore National Laboratories, which is the flagship facility for ICF research in the US. According to the recently released (12 February) Department of Energy (DOE) Budget Request, the proposal to ramp down support for the LLE and its "aged Omega Laser Facility" is part of a move to "rebalance the ICF program to strengthen longer term support for SSP [stockpile stewardship program] as well as respond to higher NNSA [National Nuclear Security Administration] priorities." The Nike laser at the US Naval Research Laboratory in Washington is also threatened with closure with the proposed withdrawal of its DOE funding. The 56-beam krypton fluoride laser operates in the ultraviolet at
$248 \mathrm{~nm}$ and delivers $4-5 \mathrm{~kJ}$ per pulse and is also used for laser-plasma and ICF-related research. Other ICF research facilities, namely NIF at Lawrence Livermore National Laboratories and the Z-pulsed power facility at Sandia National Laboratories, are expected to continue to be funded.

\section{The LLE is home to more than 350 science and engineering staff.}

However, the fate of Omega is not yet sealed and it is still far from clear what will ultimately happen. The proposed DOE budget has not yet been passed through Congress who will sign off on the final spending plans and it is proving to be controversial with many scientists and senators lobbying against the proposal to cut the funding to the LLE and close Omega. According to a recent news report in Science (go.nature.com/2pekckh), a petition calling for "the US government to reverse this misguided decision" has been signed by 51 fusion researchers across Europe and has been sent to the US Energy Secretary Rick Perry. Researchers from the UK (University of Oxford, Imperial College, Rutherford Appleton Laboratory and the University of York) and France (CEA and University of Bordeaux) have close links with the Omega facility and regularly spend time there to conduct experiments. The expertise of the LLE in high-power lasers has seen it provide speciality coated-optics for use at NIF in the US, the Megajoule laser in France and the Extreme Light Infrastructure (ELI) project under construction in eastern Europe.

The LLE is home to more than 350 science and engineering staff, and over 100 graduate students from multiple institutions are conducting research at its laser facilities. Since the founding of the LLE, more than 500 students from the University of Rochester and other major universities have obtained their doctorates based on research at the LLE.

Local to Rochester, there are worries about the economic fallout from the closure of the lab. Charles Schumer, the Democrat senator for New York State, has publically stated that he strongly opposes the closure of Omega and the LLE and is campaigning to provide the LLE with US\$75 million in funding for the fiscal year 2018, followed by a further US\$245 million in the 2019-2023 period. In response to the budget request, the University of Rochester issued a statement saying: "We are trying to make sense of this proposal [2019 PBR], which jeopardizes the cutting-edge science and world-class education being conducted at the Lab. The Lab is exceeding all its scientific milestones set by the US Department of Energy and has grown to be DOE's largest university-based research center in the nation."

The LLE may not be the only casualty of the pressure on the upcoming DOE budget. The National Renewable Energy Laboratory (NREL) in Colorado, which conducts research into photovoltaics and solar cells among other green energy sources, may see its federal budget cut in half from US $\$ 327,000$ to US $\$ 158,000$, if plans proceed as outlined.

As for other large-scale photonics facilities that fall under the umbrella of DOE funding it is better news. The 2019 PBR proposes that US\$760 million is put in place to support the construction of "next generation scientific facilities and tools" including LCLS-II - a hard X-ray free-electron laser that is an upgrade to the existing Linac Coherent Light Source (LCLS) at Stanford as well as the construction of the Advanced Light Source Upgrade (ALS-U), a soft X-ray source at Lawrence Berkeley National Laboratory.

Published online: 29 March 2018 https://doi.org/10.1038/s41566-018-0158-8 